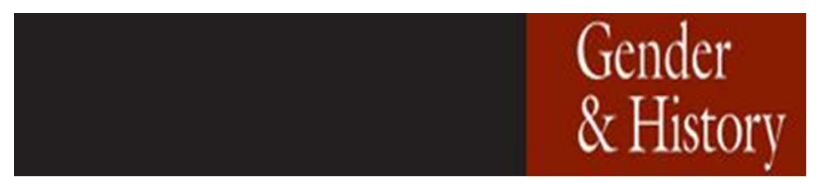

Mobility, Gender and Empire in Maria Graham's Journal of a Residence in India (1812)

\begin{tabular}{|r|l|}
\hline Journal: & Gender \& History \\
\hline Manuscript ID & G\&H-Mar-2016-0028.R2 \\
\hline Manuscript Type: & Original Article \\
\hline Keywords: & Mobility, India, Space, 'Long' eighteenth century, Imperialism \\
\hline \multicolumn{2}{r}{} \\
\end{tabular}

SCHOLARONE $^{\mathrm{M}}$
Manuscripts 
Mobility, gender and empire in Maria Graham's Journal of a Residence in India (1812)

\section{ONNI GUST}

This article focuses on Maria Graham's Journal of a Residence in India (1812) in order to examine the role of mobility in the configuration of difference in the British Empire at the turn of the nineteenth century. It shows how Graham's reading and representation of bodies in India as frenetically active, directionless or completely still, enabled her to configure Indians as inherently inferior to Europeans, where bodies moved with purpose, effecting 'progress' and 'civilization'. Her characterisation of India as a 'stagnant' civilization drew on, and resonated with, contemporary European accounts of India. Yet unlike her male counterparts, Graham elided a gendered discourse of 'effeminacy' and 'emasculation', replacing it, instead, with a discourse of mobility as a key signifier of inferiority. Placing Graham's Journal in the context of the consolidation of East India Company power in Western and Central India, the article argues that Graham's use of a discourse of mobility formed part of the construction of a 'grammar of difference' that provided the cultural foundations of imperial rule. 


\title{
Mobility, gender and empire in Maria Graham's Journal of a Residence in India (1812)
}

\author{
Onni Gust
}

'A book by a young lady, who probably went to India like most young ladies, to procure a husband instead of information, is a literary curiosity which we are not disposed to overlook'.

In 1812, the Quarterly Review published an article reviewing Journal of a Residence in India by Maria Graham (née Dundas, later Lady Callcott, 1785-1848), one of the first examples of British women's travel writing on India. Given the reputation of the Quarterly for ignoring or vilifying women's writing, the main body of the review was surprisingly positive. ${ }^{2}$ Yet it began with the condescending preamble quoted above, which portrayed Graham as dis-oriented and misdirected and her work as out of place, a 'literary curiosity'. As a 'young lady', Graham had, the Quarterly implied, inadvertently wandered into an inappropriate sphere, her travel writing represented a frivolous deviation from the 'proper' path of heterosexual marriage, reproduction and the making of home. By questioning Graham's motives for travel, the Quarterly re-oriented Graham's ambitions away from knowledge formation and towards family formation, reminding her, and prospective female writers, that their relationship to knowledge was secondary to their position as future wives in the home. The preamble to the Quarterly's review of Graham's travel narrative provides an example of the way that discourses of mobility and movement function to 
configure the meaning of bodily difference in relationship to space. Focusing on the content and context of Maria Graham's Journal of a Residence in India, this article explores the role of mobility in the configuration of difference in the British Empire at the turn of the nineteenth century. By reading Graham's Journal of a Residence in India against the grain, I show how her erasure of Indian people's labour and her simultaneous representation of their bodily movements as circular and frenetic, or as completely immobile, enabled her to construct herself as a free and individual agent. In doing so, she configured herself in relationship to a wider understanding of Europe, and of England in particular, as the epitome of 'civilization' and of progress that justified the subordination of India as a space and society. Graham's discourse of mobility thus formed a part of the construction of the 'grammar of difference' that provided the cultural foundations of imperial rule. ${ }^{3}$

Maria Graham's Journal of a Residence in India (henceforth, 'Journal') documents her travels around India, including a number of sight-seeing excursions in the vicinity of Bombay Mazagong, Sion, Malabar Point and the island of Elephanta - as well as a longer tour to Poonah [Pune], the capital of the Mahratta Confederacy, which took her through villages and past temples. It includes her observations of the people, architecture, and landscapes that she passed as she travelled to Colombo, Madras, and Calcutta, as well as discussions of the towns themselves. In form and content, Graham's Journal bears close resemblance to William Hodges' Travels in India (1793) and she, like Hodges, included sketches of architecture and landscapes. ${ }^{4}$ Although not the first British-imperial woman to write about India, her work provided particular 
inspiration for numerous British-imperial women who wrote of their experiences of travelling to, and living in, India during the nineteenth century. ${ }^{5}$ Anna Katherine Ellwood's Narrative of a Journey Overland from England by the Continent of Europe, Egypt and the Red Sea to India (1830), is just one example of a burgeoning genre for which Graham set a precedent. ${ }^{6}$ As historians of cultural imperialism have long asserted, European imperial writing, including travel writing, tells us more about the configuration of a metropolitan subject than it does the society and geography that it purports to represent. Mary Louise Pratt has shown how travel writing was fundamental to the construction of a hegemonic vision of the world - 'a European planetary consciousness - which enabled an imperial mentality and justified imperial expansion and exploitation. $^{7}$

Once remembered only for her children's history, Little Arthur's History of England (1835), Maria Graham, later Lady Callcott, has garnered increasing scholarly attention for her engagement with, and contributions to, the construction of scientific knowledge. Graham was known to the wide circle of 'bluestockings' - upper and middle class women who discussed and published on science, politics, literature and history, despite the disapprobation of patriarchal society. As Carl Thompson has shown, Graham's observations on an earthquake in Chile reveal her very sophisticated knowledge of geology and the techniques of empirical observation. Equally, the dismissive and condescending response that her observations received from the President of the Geological Society, George Greenough is evidence of the barriers and prejudices against female scientists faced at the turn of the nineteenth century. ${ }^{8}$ As a literary genre, 
however, travel writing was available to educated women in a way that history, philosophy or science was not, and as such it represents a fundamental means by which British women could intervene in the construction of knowledge and the configuration of identity in space. ${ }^{9}$ It is no surprise, therefore, that Graham chose this genre to begin her literary career, or that it was particularly through travel writing that she garnered encouragement, affirmation and support of a wider literary circle. In contrast to her travel writing, her second publication, Letters on India (1814), like her later 'An Account of Some Effects of the Late Earthquakes in Chili [sic]', received derision for its overt claim to advance knowledge and to speak authoritatively on subjects such as religion, history, architecture and geology.

Recent historians of British and European women scientists in general, and Graham in particular, have, rightly, foregrounded the latter's achievements and contributions to scientific debate. ${ }^{10}$ Yet they have been less critical of their positions as white women in relationship to imperial power. Although subordinated under patriarchy, in the context of empire white women's European heritage placed them in a position of relative power vis-à-vis colonised populations. ${ }^{11}$ Historical and literary discussions of British women's travel writing in empire in general, and India in particular, have focused on the particular position from which they wrote and on the specific nature of the white, female gaze. Sara Suleri's influential discussion of 'the feminine picturesque' understands white women's representations of imperial India as confined to the realm of the ethnographic and aesthetic. Their descriptions of Indian bodies, clothes and comportment, Suleri argues, served to tame and domesticate the environment, whilst the 
slippages into the beastly or pestilential reveals the anxiety associated with being on the margins of the colonial project. ${ }^{12}$ Much of Graham's Journal supports Suleri's analysis, yet I argue that it is specifically through a discourse of mobility that Graham configured the differences between 'India' and 'Europe' and thereby position herself as a 'civilised' woman. At a moment of changing representations of India in the colonial imaginary, Graham constructed India as a space of stagnation, decadence and decline, using verbs of movement to configure difference without recourse to the gendered language of 'effeminacy' and 'emasculation' that was employed by her male contemporaries. As such, Graham's Journal is evidence of the way that the struggle of relatively elite, white women to effect agency through knowledge formation at times took place through the objectification and denial of those situated in different, but intersecting, positions of oppression.

As Charlotte Mathieson has shown for English novels in the later nineteenth century, mobility is pervasive in literature, shaping the meaning of space, including nation-space, in relationship to bodies. ${ }^{13}$ Verbs of movement not only described the literal direction of a character's travel, they played an important role in constructing character development and narrative plot. At the turn of the nineteenth century, British writers used verbs of movement such as 'wandering', 'carousing' and 'roaming' to assert moral messages, where a lack of direction was in implicit contrast to knowing one's place and path. The 1785 edition of Samuel Johnson's A Dictionary of the English Language noted that the verb 'to wander', 'has always a sense of either evil or flight, and imports either idleness, viciousness or misery'. ${ }^{14}$ Verbs of movement 
and mobility conveyed moral messages that connected bodily movement, gender and new ideas of bourgeois respectability. This is evident in Elizabeth Bond's short story in her collection of stories, anecdotes and observations, Letters of a Village Governess (1814), in which, 'Industry, instead of carousing at markets, and spending his money among his idle neighbours, preferred his wife and pleasant home, where peace and happiness loved to dwell' ${ }^{15}$ In direct relationship to gender and travel writing, Mary Wollstonecraft's A Vindication of the Rights of Woman (1792), critiqued women's 'frivolous' and aimless travel, and placed it in contrast to men's directed journeying, with an aim and purpose in mind. ${ }^{16}$

\section{Maria Graham and the Journal of a Residence in India}

Maria Graham was an able-bodied woman from a relatively wealthy, if not elite, British family. She was an imperial subject; formed, disciplined and enabled by the vagaries of British imperial expansion at the turn of the nineteenth century. Her life history was tied-up with the fortunes of the British imperial state, whose loss of control over the thirteen American colonies and tightening grip on the activities of the East India Company in India impacted her own movements and prospects. Growing up in the shadow of the American, French and Haitian revolutions, Maria Graham's life spanned a period of rupture in the entanglements that bound British, European and colonial histories. What Mrinalini Sinha calls the 'imperial social formation' - a concept that brings together imperial aggrandisement and the social, cultural and 
ideological changes that functioned to explain, order and make sense of a new landscape - was undergoing radical reconfiguration at the turn of the nineteenth century. ${ }^{17}$ Graham grew up on the West coast of England, first in Douglas on the Isle of Mann and then in Wallasey, Cheshire as her father, George Dundas, followed employment as part of the Revenue Service and later the Admiralty. Her extended kinship network included men such as Sir David Dundas, who occupied the upper echelons of the imperial state. ${ }^{18}$ As 'the youngest son of a younger brother of Dundas of Manor', however, her own father's position and status was very much on the edges of influential, elite society. ${ }^{19}$ Her maternal family were merchants with connections between Liverpool and Virginia, where her mother was born and lived until the death of her own father during the American War of Independence. In 1808, Graham and her sister accompanied their father to Bombay to take up his position as Commissioner of the Navy. On the voyage, she was engaged to Captain Thomas Graham, who she married in 1809 and whose movements between Bombay, Madras and Calcutta dictated her own travels. The Grahams returned to Britain in 1812, largely based between Edinburgh and London, with a tour of Italy in 1815. Six years later Maria and Thomas Graham were preparing to set sail for South America, where she stayed for three years despite her husband's death in 1822, living between Brazil and Chile and continuing to write her observations and experiences. ${ }^{20}$

As this brief biographical sketch makes evident, movement was an almost constant presence in Graham's life. Indeed, it was primarily through her own 'wandering' that she made her name as a writer, publishing, in addition to the Journal, Letters from India (1814), Three 
Months Passed in the Mountains East of Rome, during the Year 1819 (1820), Journal of a Residence in Chile, during the Year 1822; and a Voyage from Chile to Brazil, in 1823 (1824), as well Little Arthur's History of England (1835). According to her autobiographical reflections, as a girl Graham was discouraged from intellectual activities by her family but gained access to books, including Virgil's Illiad, the Odyssey and Shakespeare, whilst at a small school for girls in Abingdon, near Oxford. ${ }^{21}$ Graham seems to have developed an early consciousness of women's oppression in society and particularly the barriers imposed upon women's learning. Her diary of 1806 includes a series of notes and quotes about the position of women in society based on reading Dugald Stewart's Philosophy on the Human Mind and the Tacitus' Annals. ${ }^{22}$ Although she appears not to have corresponded with 'bluestockings' such as Elizabeth Hamilton, she was known amongst the wide literary and intellectual society of Edinburgh and retained a lifelong correspondence with its leading publishers, John Murray and Archibald Constable, the latter of whom published the Journal. ${ }^{23}$

\section{Imperial power and mobility}

If the publication of Graham's Journal was the result of her contacts amongst Edinburgh's relatively elite literary society, its specific content and subject matter was accessible to her only as a result of recent and still precarious consolidation of power by the East India Company in Western and Central India. When Graham set sail for Bombay in 1808, Western and Northern 
India were in a state of devastation following the Second Anglo-Maratha war in which the East India Company had gained territory in Gujarat to the North of the port city that enabled the establishment of the Bombay Presidency. ${ }^{24}$ Bombay itself had been held by the Crown and rented to the East India Company since 1661 and was a relatively flourishing port-town, a key node in trade networks between Europe, India and China and the base of the Bombay Marine. ${ }^{25}$ Yet British dominance over the wider region of Western and Central India was partial and insecure. With hindsight it is easy to see Tipu Sultan's death in 1799, which ended the AngloMysore wars, as the beginning of East India Company dominance. Yet its subjugation of the warring Maratha rulers was far from complete and the mutinies, rebellions and renewed hostilities were a constant threat. Indeed, Graham's father, Admiral George Dundas, was likely to have been sent to India as a result of the change in administration in Madras after the Vellore mutiny of 1806-7, in which sepoys serving in the Madras Army rose up, supposedly in protest against new head ware regulations. ${ }^{26}$ The subsequent 'White mutiny' of 1809 , which spread across the Madras Presidency, from Masulipatam [Machilipatnam] to Madras and Seringapatam [Srirangapatna], made clear the shakiness of East India Company rule. ${ }^{27}$

Graham's Journal cannot be divorced from its context of the consolidation of the East India Company rule in southern India and Ceylon. Graham travelled across the Deccan and to Ceylon [Sri Lanka] as part of an imperial party, which included Colonel John Mackenzie, who would become Surveyor General of Madras the following year. ${ }^{28}$ As such, Graham's journal was embedded and enabled by imperial power and reliant on the co-operation of subject populations. 
Like the majority of European travellers during the period, Graham and her elite, imperial party travelled with a vast retinue of servants who carried and protected their baggage and their bodies, set up tents and cooked their food. Describing an excursion along the South West coast of Ceylon in February 1810, she stated that:

First our palankeens and servants went over in two or three small boats lashed together, and with them a number of people carrying lights; then all the village musicians in separate boats, having also their lights; and lastly our boat, dressed with white cotton, flowers and leaves, and illuminated with the dried coconut leaves. ${ }^{29}$

The detailed picture of imperial travel that Graham provides reveals the enormous number of people, materials and infrastructure that imperial mobility required, even for relatively short excursions. The European party were carried by their palankeen bearers from place to place, whilst preparations, referred to as 'dressing' the road, were made for their arrival ahead of them. Their visit to Barbareen [Barberyn], for example, necessitated the construction of a 'bungalow of bamboo, covered with cotton cloth, and decorated with leaves, flowers, and bunches of coco-nut by way of capitals to the pillars', as well as the erection of a temporary bridge. ${ }^{30}$

Yet despite the detailed description of the materials and modes of travel, Graham obscures or downplays the role of local, indigenous people in enabling her mobility, whilst simultaneously employing mobility as a trope to perform European superiority. For example, Graham is ambiguous about who provided the infrastructure that allowed her to traverse rivers and travel 
along roads in Ceylon. According to her, passage and accommodation in Ceylon were provided by the Modeliar [mudaliyars] or headman, of the region. ${ }^{31}$ Yet it is unclear how far the headman's supply of accommodation and passage was an obligation placed upon him by the East India Company, as one of the means by which it asserted its power over space. Graham claimed that such provisions were paid for 'punctually' by the English, whereas they had been previously demanded as a form of tribute by the Dutch, who controlled most of Ceylon until the British annexation in 1795 , ostensibly to protect it from the French. ${ }^{32}$ This 'annexation' was consolidated in 1802 as part of the Treaty of Amiens and, as Alicia Shrikker notes, was of very questionable benefit to the Sinhalese population. ${ }^{33}$ Later, however, Graham contradicted her own assertion by stating that, 'the dressing of the road for persons of consequence in the government, is a tribute from the fishermen of this coast, and so is the providing lights at night' ${ }^{34}$ She further undermined this claim by minimising the extent of the labour required to convey her and her party, stating that 'the dressing [of] the road and rest-houses, as it is seldom required, and is performed chiefly by the women and children, is no heavy burden, and is merely exacted as a mark of respect to the officers of government'. ${ }^{35}$ Reinforcing patriarchal notions of what and whose labour can be considered meaningful, Graham dismissed the significance of the labour of 'dressing' the roads for her party's benefit. The work of 'dressing' the roads becomes, for Graham, superficial and thus insignificant, which enables her to effect a domination of space without acknowledging her dependence on the people living under British imperial rule. 
Graham's ambiguity about the role and significance of the local, indigenous population in effecting her own mobility creates a distance between herself as mobile, agentic subject and the objects of her discussion, who she represented as static and immobile. The simultaneous revealing and denying of her reliance upon the local population for her mobility is evident in her description of hamauls, or palankeen [sic] bearers, who she encountered immediately on her arrival in Bombay. Palankeens were much like carriages but rather than being dragged by horses, they were carried on four sides by men who ran to a steady rhythm marked by what Graham referred to as a 'monotonous song, ${ }^{36}$ The description of the song as 'monotonous' suggests that the palankeen bearers are not, themselves, going anywhere meaningful, which effects a separation between them and the purposeful Europeans whose white bodies they bear. Indeed, Graham's initial description of the hamauls used the colour of skin to reinforce difference: 'They for the most part wear nothing but a turban, a degree of nakedness, which does not shock one, owing to the dark colour of the skin, which, as it is unusual to European eyes, has the effect of dress ${ }^{37}$ Graham's focus on the hamauls' dark skin, which acts as a cover, taking on the characteristic of clothes, acquits her of any accusation of voyeurism. Yet it also creates a complete separation between white European and dark 'native,' a discursive manoeuvre that Sara Suleri, in her discussion of Fanny Parks' Wanderings of a Pilgrim in Search of the Picturesque (1850), argues enables the aesthetic commodification of Indian bodies. ${ }^{38}$

The objectification of the hamauls' bodies allows Graham to obscure her reliance upon them for her own mobility and place them, instead, into the realm of the picturesque. Rather than 
being the vital means by which Graham reaches her destination, they become, instead, mere objects of observation, disconnected from her own mobility and divorced for her own position as a white, European woman in India. Her representation of their nakedness thus mirrors her ambivalence about the significance of the 'dressing' of the roads. Whether the hamauls or the roads are dressed or undressed, is irrelevant to Graham, for she refuses to attribute any meaning to them beyond the aesthetic. In her Journal, the dressing of the roads is a superficial act, whilst the nakedness of the hamauls is rendered meaningless because their skin colour effects an absolute difference that makes the penetration of meaning impossible. This enables Graham to deny the significance of both the bodies who convey her and the bodies who labour to prepare the roads along which she travels. Paradoxically, the close attention that her narrative pays to the means and modes of conveyance draws attention to her reliance upon the labour of indigenous people who effected her journey.

\section{Mobility and the 'grammar of difference'}

Graham's travel relied fundamentally on the precarious power that the East India Company exerted over people, resources and environments in the parts of India that Graham visited. Confined to the realm of the aesthetic and ethnographic, Graham's representations of Indian people appear dis-interested and dis-invested in the wider project of empire and thus contributed towards the circulation of a discourse of difference in a way that appears innocent of power. ${ }^{39}$ 
Yet not only were her travels fundamentally enabled by East India Company control of regions, roads and resources, her encounters and representations of Indian people were embedded in the context of political control. This is apparent in her pejorative representation of the Peshwa Baji Rao II, who she never actually met but who she determined, based on hearsay, to be, 'a man of little or no ability, a great sensualist, and very superstitious. His time is spent in making pilgrimages, or buried in his zenana'. ${ }^{40}$ Graham's brief discussion of the Peshwa took place in the context of her participation in a tour of the Deccan in December 1809. Her party consisted of 'one lady, two gentlemen, and three children', alongside Graham's father, sister and probably also her newly-wed husband, as well as 'near two hundred' attendants. ${ }^{41}$ The lands through which Graham toured had been recently devastated by war over territory and power between Tipu Sultan, the Nizam of Hyderabad and Maratha factions. In 1802, one of the leading Maratha houses that had emerged under the first Peshwa Baji Rao in the early eighteenth century, plundered Pune. The Peshwa Baji Rao II to whom Graham referred fled to Bassein, signing a treaty that gave the British territory in Surat and revenue-producing lands. ${ }^{42}$ The alliance with the British meant that all except his nominal title was taken on by a British Resident, leaving him as head of the Marathas in name alone. ${ }^{43}$

In implicit contrast to her own party's purposeful and directed travel, Graham represents the Peshwa's mobility as borne of superstition, as frivolous and irrational. His pilgrimages and processions suggest circularity, a perpetual but unproductive motion, whilst the alternative to these endless and pointless pilgrimages was his "burial” in his zenana. Graham's portrayal of the 
Peshwa fundamentally undermines the importance of pilgrimage and the circulation of deities to the assertion of political sovereignty in eighteenth-century Mughal-dominated court practices. ${ }^{44}$ She also obscures the role of the wider political context in circumscribing the Peshwa's movements, as well as the East India Company's own role in disrupting established trade networks, and thereby political power, and limiting mobility. ${ }^{45}$ Graham's undermining of the Peshwa's character using a discourse of immobility, stagnation and directionless-ness complemented the East India Company's claim to political dominance over the Maratha ruling house.

At a more local level, Graham used the same discourse to signify the differences between nominally 'British' and 'Indian' spaces in the city of Bombay. In Graham's Journal the streets, traffic and houses of Bombay symbolised the differences between 'European' and 'native' populations. Describing the Black Town of Bombay, the centre of commerce and residence for Bombay’s Parsi, Hindu, Armenian and Muslim populations, Graham focused on crowds and congestion. 'The streets appear so crowded with men, women and children, that it seems impossible for the quiet bullock hackrays, or native carriages, to get along without doing mischief' ${ }^{46}$ This picture of congestion and disorder is in direct contrast to the dock yard, owned by the East India Company, 'the most important and interesting object in the fort' ${ }^{47}$ Unlike the Black Town with its chaotic jumble of 'furiously driving coaches', hackrays and bullocks, the harbor, with its new dock is filled with 'vessels from all nations' opens up trade, encouraging circulation and commerce. ${ }^{48}$ Graham's representation coincided with attempts by Bombay’s 
government to reorganise the city space and relocate less desirable members of its residents beyond its walls. ${ }^{49}$ Although Graham herself had no role in the negotiations between the public department and the Parsi, Armenian, Muslim and Hindu populations of Bombay, her representation of the city space and its inhabitants contributed towards creating a picture of chaos upon which the government sought to impose order.

A similar contrast takes place in relationship to the houses of 'natives' and Europeans. In Graham's representation, even the large houses belonging to the extremely wealthy, mainly Parsi, elite of Bombay, mirrored the crowded chaos of the streets. 'The houses are necessarily of great extent, because, if a man has twenty sons, they all continue to live under the same roof even when married ${ }^{50}{ }^{50}$ The European houses, conversely, were bright and airy. The windows, the veranda, the large, sculpted gardens with paths for taking walks, allowed for circulation of airs and of people, enabling mobility. ${ }^{51}$ Yet in Graham's account it is not simply the ability to move around within a house that separates European from 'native' dwellings. In her description of the house in which she, her father and sister stayed, Graham lays emphasis on the ability to 'admit or exclude the air as we please' ${ }^{52}$ The command of the weather and the choice of whether to be enclosed or free to walk at will further distinguishes the mass of 'native' bodies from the individuality and agency of elite European colonists. Graham's attention to the ability to move through and around houses went hand-in-hand with the ability to command. In Ceylon, the rooms of the governor's country-house, Mount Lavinia, 'command some pretty views', whilst the residence of Sir James and Lady Mackintosh just outside of the centre Bombay, in Tarala, 
'commands on all sides charming views'. ${ }^{3}$ The houses of her European friends thus become the sites from which to construct the picturesque, and thereby extensions of European dominance over a colonised landscape.

In Graham's narrative, the European controls the environment and has a command over the landscape, whilst the 'natives' become a part of it. Arriving in Madras, she stated that, 'The beach is crowded with people of all colours, whose busy motions, at that distance, make the earth itself seem alive'. ${ }^{54}$ Yet if from a distance, the earth and the people blend into one creating a sense of animation, upon closer inspection, Indian people appear immobile, inanimate and destined only for death. Like the Peshwa's ultimate 'burial' in his zenana, Graham's description of a wedding procession imagined the young bride and groom as 'little victims going to sacrifice'. ${ }^{55}$ During one of her walks around the environs of Bombay, Graham 'followed a pretty child into a hut' where she met a woman cooking and nursing a child. This woman, 'told me that she sat at her occupation from sunrise to sunset, and scarcely changed her position' ${ }^{56}$ Yet even when the inhabitants of the cottage did move, to attend a wedding, Graham still imagined them to be immobile and suspended in time. Following the group in order to watch the marriage procession, she stated that they 'looked like the groups we see on antique bas-reliefs' ${ }^{57}$ The 'arts and virtues' of Antiquity were, however, missing from the landscape, 'sunk in the years of slavery under which the devoted Hindoos have bent', leaving only a 'meek' but 'cunning' population. ${ }^{58}$ 
Graham's use of (im)mobility and movement to configure 'Hindu' bodies as simultaneously frenetically mobile, directionless and static, enabled a wider representation of India as a 'stagnant' and 'backwards' civilisation. Drawing broadly on an Enlightenment paradigm, she understood India as a 'stagnant' civilization that had reached its pinnacle of arts and learning hundreds of years prior to European encounter. What remained in the India of the early nineteenth century were the corrupted remnants of that 'Hindu' civilization, remnants that could provide a window onto Europe's own antiquity. Muslims, on the other hand, represented an invading force and the Mughal Empire a waning power whose control of 'their' women signified tyrannical power and 'bigotry'. ${ }^{59}$ Graham's invitation into the Shabab o'dien Mahayr's harem enabled her to describe some of the wealthiest members of Bombay's Muslim population. Here, too, lack of mobility goes alongside indolence and enslavement. Graham described Shabab o'dien Mahayr's wife, Fatima, as 'modest, gentle and indolent' and noted that 'she hardly moves without permission from the elder ladies of the harem ${ }^{90}$ Fatima's own lack of mobility, except at the assent of her husband or her elders, and 'indolence' maps on directly to the space that the women occupy. In implicit contrast to her own house, Graham described the dimensions of the room as 'rather low' and surrounded by smaller rooms, 'most of them crowded with small beds, with white muslin curtains, these were not particularly clean, the whole suite seemed close and disagreeable'. ${ }^{61}$

Graham's description of the claustrophobia of the apartment slips effortlessly into a description of the 'indolence' and immobility of the women themselves. 'Prepared as I was to 
expect very little from Mussalmen ladies, I could not help being shocked to see them totally devoid of cultivation as I found them. They mutter their prayers and some of them read the Koran but not one in a thousand understands it' ${ }^{62}$ Unlike Lady Mary Wortley Montagu's romantic depictions of the regality and beauty of the Turkish harem in Embassy Letters, published posthumously in 1763, Graham was dismissive of the women's lack of learning and understanding. ${ }^{63}$ 'They thread beads, plait coloured threads, sleep, quarrel, make pastry, and chew betel, in the same daily round; it is only at a death, a birth or a marriage, that the monotony of their lives is ever interrupted' ${ }^{64}$ Despite gender, class and religious differences, the unchanging, cyclical routine of the women of the harem evokes the same purposelessness that Graham attributes to the Peshwa's pilgrimages and the palankeen bearers' mobility. The 'monotonous song' of the latter suggests that their movement is aimless and purposeless, whilst the Peshwa's 'squandering' of 'immense sums' on 'some devout procession' denies meaning to his mobility. ${ }^{65}$ The circularity of the processions and the purported futility of the Peshwa's spending is mirrored in the women's repetitive activities and speech. They 'mutter' words that they do not understand and 'quarrel' rather than converse or debate. The repetition of words and acts signifies a wider sense of directionless and circularity, which condemns Graham's subjects to perpetual stagnation in time and in space.

\section{Mobility and the construction of 'Europeanness'}


Graham's pejorative description of Fatima and her sisters, and of the Peshwa Baji Rao II, as well as her fixation on the immobility of Indian people in general supported and circulated Orientalist constructions of India as a civilization that had degenerated into decadence and indolence. ${ }^{66}$ Her representation of Indian people as static and immobile or, alternatively, frenetically mobile and directionless implies a contrast with her own purposeful travel and command of the landscape. Yet the axis of difference along which Graham configured the meaning of 'European' and 'Indian' was not a straight-forward binary. As Ann Laura Stoler has argued for the Dutch East Indies in the mid nineteenth century, the apparent homogeneity of 'European' communities in the colonies was a charade manufactured by the colonial government. ${ }^{67}$ At the turn of the nineteenth century, when systematic controls to prevent racial mixing were less embedded in structures of rule, the distinctions between the behaviours and attitudes of 'white European' and non-white 'native' were also less marked. ${ }^{68}$ Graham's observations contributed towards that demarcation and configured, at the same time, the meaning of 'Europe'. Here, too, mobility was a key tool in that construction of difference.

Although she slipped between 'European', 'English', 'white' and 'Anglo-Indian' to denote the society of people with European heritage, the majority of whom worked for the East India Company, Graham made a clear distinction between those who truly belonged to 'civilized' Europe and those whose residence in India undermined any claim to European or English identity. Europe - 'where the mind of man seems to flourish in preference to any other land' represented geographical space, a cultural performance and identity. ${ }^{69}$ Amongst the people with 
whom Graham lived and socialised in Bombay, Madras and Calcutta, she appreciated most those 'whose society reminded me of that we have enjoyed together in Britain' ${ }^{70}$ Yet the majority of the colony's colonial residents, despite their white skin and European heritage, did not conform to this model of Western, bourgeois sociability. 'The avarice, the prodigality, the ignorance, and the vulgarity of most of the white people [in India]', placed them, Graham claimed, on the same level as the 'passive submission of the Hindoos [sic]; the more active fanaticism of the Mussulmans', all of whom were 'infinitely below that of the least refined nations of Europe'. ${ }^{71}$

Again, Graham conceptualised the inferiority of 'most of the white people' using the language of mobility. Describing a typical day in the life of 'all the gentlemen and ladies of Madras' (the white people to whose 'vulgarity' she referred), Graham presents an image that resonates with her discussion of the Black Town in Bombay or the processions of the Peshwa in Pune:

It is the fashion for all the gentlemen and ladies of Madras to repair, in their gayest equipages, to the Mount Road, and after driving furiously along, they loiter round and round the cenotaph for an hour, partly for exercise, and partly for the opportunity of flirting and displaying their fine clothes, after which they go home, to meet again every day in the year. ${ }^{72}$

The dullness of life in Madras, or in Bombay is here signified by the white residents' futile and circular mobility. They 'loiter', they drive 'furiously' but without purpose or direction, they 
repeat the same activities every day, trapped in a cycle of monotony and stagnation. Their afternoons, Graham claimed, were spent in a train of frivolous visitations, a procession of 'idlers' who are entertained with food, wine and beer, after which the ladies retire to lie down and sleep.

The monotony and dullness of white society was a constant theme, not only in Graham's Journal but in the letters and diaries that her elite, European contemporaries wrote from India. 'I think the mind seems very materially changed by crossing the sea', wrote Sir James Mackintosh (1765-1832), Recorder of the Court, with whom Graham and her family stayed upon their arrival in Bombay. 'Every Englishman who resides here very long has I fear his mind either emasculated by submission or corrupted by despotic power'. ${ }^{73}$ Employing, like Graham, the image of crowds to indicate an inability to progress, Mackintosh stated that, 'My understanding is indeed in almost absolute solitude and my body is too often in a croud [sic] ${ }^{9}{ }^{74}$ His complaints drew on a much wider understanding of the beneficial effects of free movement and circulation at multiple and interconnected levels. Mobility - the circulation of bodies, airs, conversation and ideas - enabled discovery, civilization and progress. Adam Smith's Wealth of Nations (1776) had argued for the benefits of commerce as a form of circulation, the free movement of capital mirroring the movement of people, ideas and conversation. ${ }^{75}$ In India, however, the environment itself posed a threat to the ability of the body to move, potentially stifling the progress of the social body of 'Europe' itself. 
The rapid economic development, which placed the British Isles at the forefront of what eighteenth-century political economists understood as 'civilization', would have been impossible without the exploitation of India's material resources and trade routes. Yet for contemporary thinkers, India was also fraught with hidden dangers that posed a threat both to the 'European mind' and to the progress of civilization. The threat of Indian degeneracy was embodied in landscape and nature. The beautiful gardens that suggested the possibility of walking freely in pursuit of botantical and anthropological knowledge, would, Graham claimed 'be a little paradise, but for the reptiles peculiar to the climate'. ${ }^{76}$ The rock snake, the cobra capella and the white worm whose eggs penetrated and implanted themselves in human skin, threatened either to instantly end or deform the progress of a freely walking European. The picturesque landscape 'flowering shrubs of most delicious perfumes, and creeping-plants of every various hue' - was deceptive. Hiding behind its beauty, the tiger 'prowls through the overhanging forest' and the 'serpent lurks beneath the many-coloured bower' ${ }^{77}$

For Graham, the inability to walk through the Indian landscape was one significant marker of difference that separated European and Indian environments and mapped onto their peoples and cultures. She was not alone in understanding walking, especially amongst nature, as a sign of freedom and independence. ${ }^{78}$ Locke had used walking as key means to illustrate his definition of freedom as the power to effect what a man wills. ${ }^{79}$ In his discussion of the innate characteristics of human beings as part of Physical Geography (1802), Immanuel Kant employed walking for pleasure as a marker of difference between Indians and Europeans. According to Kant, the 
'lethargy' and 'laziness' of the inhabitants of the 'hottest zones' meant that unlike a European, an

to Indian people - timidity, superstition, jealousy, idolatry, slavishness - Kant made clear that walking was a virtue that singled out Europeans as superior. ${ }^{80}$ In Graham's Journal this association is most evident in the representation of 'Mrs A' a resident of Salsette, one the islands that made up the wider environs of Bombay. Describing Mrs A's daily routine, Graham stated that:

She is blessed alike by the old and the young; she knows all their wants, and listens to all their complaints. There is no medical man within many miles, and I have seen her lovely hands binding up wounds which would have sickened an ordinary beholder. The work of charity over, she enjoys a walk amidst these beautiful scenes with all the gaiety natural to her age. ${ }^{81}$

In this passage, the contrast between the binding and enclosing of wounds and the freedom and mobility of Mrs A's walk constructs the differences between 'native' and 'European'. Here, mobility in general, and walking in particular, becomes the symbol of 'Europeanness' and simultaneously a marker of virtue.

Despite the fact that the Vauxhall Gardens in London were as much scenes of 'loitering' as Mount Road in Madras, that the streets of East London were as congested as those of the Black Town of Bombay, and that the parlors of English country houses were widely regarded as sites 
of dull and repetitive ceremony, Graham understood Asia and Europe to be diametrically opposed to each other. ${ }^{82}$ Her explanation for what she called the 'great moral disparity between Europeans and Asiatics' drew on the discourse of mobility, which she linked to eighteenthcentury climate theory, claiming that hot climates and abundant resources produced immobility, which in turn encouraged idleness. ${ }^{83}$ 'No incitement to exertion exist in this climate, and the mind sinks in proportion to the inactivity of the body', Graham wrote, in the conclusion to a description of the people she encountered in Ceylon, which in its details offers no evidence of apathy or immobility at all. ${ }^{84}$ This spurious construction of 'Europe' as marked by mobility and 'Asia' as immobile, enabled and justified imperial rule by representing Asians, and Hindus in particular, as innately subject. Graham's representation of immobility in India served as a sign of 'meekness' and 'patience', characteristics that had allowed India as a space and a society to remain unchanged and 'enslaved' across centuries. ${ }^{85}$ In contrast, the industry and progress of 'Europeans' directly correlated with their purposeful bodily activity. For Graham, as long as 'Europeans' retained their 'Europeanness' by resisting the degenerating effects of the climate, they would eventually bring about 'progress' in India and Ceylon.

\section{Gender, mobility and 'European civilization'}

Graham's period of residence in India coincided with significant changes in the ideologies of, and justifications for, colonial rule in India. Questions over the extent and nature of the power 
wielded by the East India Company had led to increasing jurisdiction over India by metropolitan government in London. ${ }^{86}$ In many ways, Graham's pejorative representations of Indian people and of the 'Anglo-Indian' society in Bombay, Madras and Calcutta reflected early moves towards Anglicisation. ${ }^{87}$ Her attitudes were certainly influenced by those of her host in Bombay, Sir James Mackintosh, whose own views on Indian people and on India's 'Anglo-Indian' population were derisive. ${ }^{88}$ The attitudes of both Mackintosh and Graham (although she retracted some of her more patronizing remarks in her second publication on India, Letters on India) represent precursors to the type of mindset that became hegemonic through James Mill's History of British India (1818) and Macaulay's 'Minute on Education' (1835). India, from this perspective, was less an ancient civilization worthy of respect and discovery than it was a depraved and degenerate society, which could only benefit from whole-scale British imperial intervention and the implementation of 'European' civilization.

By the turn of the nineteenth century, and much influenced by the evangelical Christian and director of the East India Company, Charles Grant (1746-1823), British writing on India placed a growing emphasis on the 'effeminacy' of Hindu men and the apparent 'barbarity' of practices relating to sex and gender. ${ }^{89}$ Enlightenment thinkers had long linked the 'torrid zone' to notions of femininity by representing non-European males as weaker, less virile, sexually promiscuous and less rational than European males. ${ }^{90}$ Yet in relationship to India, this gendered discourse became considerably more marked and pejorative. Grant's Observations on the State of Society among the Asiatic subjects of Great Britain (1792), described the 'effeminate exterior, 
adulatory address and submissive demeanor of the Hindoos [sic]' as part of his argument for Christian missionary activity in India. ${ }^{91}$ Robert Orme's Historical Fragments of the Mogal Empire (1805) included a section entitled 'On the Effeminacy of the Inhabitants of Indostan', which concluded that, partly due to climate, 'the Indian must become the most effeminate inhabitant of the globe; and this is the very point at which we now see him' ${ }^{92}$ By 1815 , William Ward's A View of the History, Literature and Religion of the Hindoos (1815), from which James Mill quoted extensively for his History of British India (1818), stated that the 'Hindoos' were the 'most effeminate and corrupt people on earth'.93

Despite the obvious influence of Enlightenment and Anglicist ideas about India on her thinking, Graham differed in never explicitly used a gendered discourse of 'emasculation' and 'effeminacy' to configure the difference between India and Europe. Instead, she used the discourse of mobility to signify the superior virtues of 'European civilization'. Mrs A's walking and appreciation for nature, for example, marked her as a civilized, 'European'/'English' woman. 'Would that there were a few more such European women in the East, to redeem the character of our country-women, and to shew [sic] the Hindoos what English Christian women are', Graham wrote. ${ }^{94}$ Although not explicitly aligned with the demand by evangelicals for greater missionary activity in India, Graham's reference to 'English Christian women' is representative of a more general turn towards understanding 'virtue' in relationship to Protestantism. This was as evident in middle-class moralising in Britain as it was in India, and was a characteristic of contemporary feminists, whose understanding of 'Christian' behaviour 
focused on 'useful' and 'directed' activity. ${ }^{95}$ Graham's use of mobility as the key marker of combined religious, cultural and national difference, then, enabled her to elide an overtly gendered discourse that equated femininity with submission, meekness, frivolousness and indolence. Instead, Graham named stillness and lack of direction a sign of social, moral and cultural stagnation and used immobility as a metaphor of degeneracy. She thus displaced the negative characteristics that were usually attributed to female bodies onto the movements of primarily non-white bodies in India, regardless of sex and attributed the difference between European and Indian mobility to the climate and environment.

In her use of a discourse of mobility rather than of gender, Graham's Journal resonates with Mary Wollstonecraft's critique of women's travel writing in A Vindication of the Rights of Woman. As part of her wider argument for female education, Wollstonecraft distinguished purposeful from frivolous movement. Wollstonecraft leveled her critique at the way 'civilized women' were taught to inhabit space, arguing that women were taught to make spectacles of themselves rather than engage in 'useful' activities. ${ }^{96}$ Claiming that her critique also pertained to 'the rich of both sexes', Wollstonecraft used the discourse of mobility to configure a 'rational' and 'useful' masculine, bourgeois subject in opposition to a misguided and decadent femininity. ${ }^{97}$ Graham used the same discourse of mobility to demarcate the boundaries between 'civilized' 'European' and particularly 'British' space from the cultural, environmental, political and religious space of India as a whole. The preoccupation with 'incidental occurrences' that Wollstonecraft accused ‘civilized women' of, resonates with Graham's description of the Peshwa 
as a 'sensualist' whose pilgrimages were frivolous, expensive and irrational. Equally, Wollstonecraft's reference to the 'listless inactivity' of women, which, she claimed, turned them into 'creatures of sensation' is mirrored in Graham's portrayal of the women of the harem. ${ }^{98}$ Both writers used metaphors of mobility to define and determine difference, setting up a binary between 'virtue' and 'decadence', which mapped on to temporal notions of 'progress' and 'stagnation'. In both Wollstonecraft and Graham's work, therefore, the discourse of mobility enabled a configuration of difference based, theoretically, not on what a body was but on how a body moved through space.

In practice, however, the meaning inscribed upon a body's movement (or lack of it) in space was based upon a simultaneous and co-constitutive reading of body and space in the context of relations of power. Graham's reading of the movements of bodies in India drew on already-established and pejorative paradigms of thought that framed India as stagnant and degenerate. Like many British writers, her search for an ancient past in the midst of the present led her to read Indian bodies as inherently immobile, even where her own testimony suggests otherwise. In contrast to the immobile population around her, Graham represented herself as an individual agent, whose movement was free and self directed. Erasing her relationship to imperial power and her reliance on Indian bodies to facilitate her travel, Graham obscured the impact of imperial expansion and rapid socio-economic change on the possibilities for movement, as well as failing to acknowledge that movement took on different meanings in 
different cultural, religious and political contexts. In Graham's Journal, therefore, mobility becomes another intersection in the configuration of difference that enabled imperial rule.

\section{Conclusion}

In their edited collection, Moving Subjects, Antoinette Burton and Tony Ballantyne state that mobility was a 'constitutive factor' in the construction of intimacies that underpinned imperial power. ${ }^{99}$ Yet despite this recognition, few historians of the British Empire have interrogated the way that mobility discursively constituted the meaning of bodies in relationship to space. This interrogation is important, not only because it adds another layer to the discourses of difference that effected and justified imperial rule in the nineteenth century, but because it sheds light on the cultural meanings that mobility accrues in different contexts. ${ }^{100}$ These meanings have a significant impact on the political, social and economic organisation of space, on which bodies can 'progress' both literally and figuratively. ${ }^{101}$ The process of inscribing the movements of certain bodies with agency, whilst denying the legitimacy of others, informed and justified imperial governance and the reordering of space. Graham's erasure of the imperial power dynamics that enabled her movement, including the labour of palankeen bearers and of the 'dressers' of roads, allowed her to perform individual agency - the cornerstone of Enlightenment rationality - whilst those same dynamics of power disabled or reoriented the movement of other bodies in space. ${ }^{102}$ 
By writing and publishing her Journal, Graham claimed the right to participate in the construction of knowledge despite the refusal of society to countenance women's learning and scholarship. The Journal and her subsequent publications were thereby acts of resistance against what Jane Rendall has called a 'masculine critical authority' at the turn of the nineteenth century. ${ }^{103}$ By representing herself as a purposeful and mobile subject in pursuit of knowledge, Graham challenged society's expectations that she orient herself solely around the home. The Quarterly's snide remark, which began this article, is illustrative of the challenge that Graham's actions posed to patriarchal power. At the same time, however, Graham's resistance to the way that misogyny played out on her own body, took place through her construction of Indian bodies as inherently inferior. Graham's emphasis on mobility as a marker of difference used types of movement as the primary means of signifying inferiority and thereby justifying imperial power. Focusing on mobility enabled Graham to elide the gendered language of 'effeminacy' and 'emasculation' used by her male contemporaries. Yet her undermining of a pejorative, gendered discourse was limited, pertaining only to white, European bodies and applied only to herself and the few 'English' women who she held up as models of 'civilized', Christian 'virtue'. Overall, Graham read mobility through the lens of established racial hierarchies that marked Indian bodies, as well as European bodies that were placed in too close proximity to India as a culture and a space, as inherently inferior. Set in the context of other European-imperial texts on India written at the turn of the nineteenth century, Graham's Journal illustrates how a discourse of mobility intersected with race, class and gender to play a significant role in the configuration of 
what it meant to be 'British', 'European' and 'civilized'. Her Journal thus contributed towards inscribing mobility with cultural meaning, in which the 'directed' and 'purposeful' movement of 'Europeans' lent further legitimacy to the imperial project.

\footnotetext{
1 ‘Art VIII Journal of a Residence in India by Maria Graham', Quarterly Review, XVI (1812), p.406.

2 Jane Rendall, 'Bluestockings and Reviewers: Gender, Power and Culture in Britain, c.18001830’, Nineteenth Century Contexts 26 (2004), pp. 355-374. See also: Jennie Batchelor, Women's Work: Labour, gender, authorship, 1750-1830 (Manchester: Manchester University Press, 2010); Mary Poovey, The Proper Lady and the Woman Writer: Ideology as Style in the Works of Mary Wollstonecraft, Mary Shelley and Jane Austen (Chicago: University of Chicago Press, 1984); Elizabeth Eger, Charlotte Grant, Clíona Ó Gallchoir and Penny Warburton (eds), Women, Writing and the Public Sphere, 1700-1830 (Charlottesville: University Press of Virginia, 2002).

${ }^{3}$ See Ann Laura Stoler and Frederick Cooper, 'Between Metropole and Colony: Rethinking a Research Agenda' in Cooper and Stoler (eds), Tensions of Empire: Colonial Cultures in a Bourgeois World (Berkeley: University of California Press, 1997), p.3. The significance of orientation as a means through which to construct norms of progress is made evident in Sara
} 
Ahmed's Queer Phenomenology: Orientations, Objects, Others (Durham: Duke University Press, 2006).

${ }^{4}$ William Hodges, Travels in India during the years 1780, 1781, 1782 \& 1783 (London: J Edwards, 1793) <https://archive.org/stream/travelsinindiad01hodggoog\#page/n5/mode/2up> ${ }^{5}$ Rosemary Raza, In Their Own Words; British Women Writers and India 1740-1857 (Oxford: Oxford University Press, 2006); Indira Ghose, Women Travellers in Colonial India: The Power of the Female Gaze (New York: Oxford University Press, 1998). Early women travel writers on India are Eliza Fay, Original Letters from India, E.M. Forster (ed) and Simon Winchester (intro.) (New York: Hudson, 2010, first published, 1817) and Jemima Kindersley, Letters from the Island of Tenerife, Brazil, the Cape of Good Hope and the East Indies (London, 1777).

${ }^{6}$ Mrs Colonel Elwood (Anne Katherine), Narrative of a Journey Overland from England by the Continent of Europe, Egypt, and the Red Sea to India including residence there and voyage home in the years 1825, 26,27 and 28, vol. I \& II (London: Henry Colburn and Richard Bently, New Burlington St, 1830).

${ }^{7}$ Mary Louise Pratt, Imperial Eyes: Travel Writing and Transculturation (London: Routledge, 1992), p.15.

${ }^{8}$ Carl Thompson, Earthquakes and Petticoats: Maria Graham, geology and early nineteenth century “polite” science', Journal of Victorian Culture 17 (2012), pp. 329-346. 
${ }^{9}$ Susan Bassnett, 'Travel Writing and Gender' in Peter Hulme and Tim Youngs (eds), Cambridge Companion to Travel Writing (Cambridge: Cambridge University Press, 2002), p. 231.

${ }^{10}$ Ann Shteir, Cultivating Women, Cultivating Science: Flora's daughters and botany in England, 1760-1860 (Baltimore: John Hopkins University Press, 1996); Patricia Fara, Pandora's Breeches: women, science and power in the Enlightenment (London: Pimlico, 2004).

${ }^{11}$ Sara Suleri, The Rhetoric of English India (Chicago: University of Chicago Press, 1989), p.75; Felicity Nussbaum, 'British Women Write the East after 1750: Revisiting a "Feminine" Orient' in Jennie Batchelor and Cora Kaplan (eds), British Women's Writing in the Long Eighteenth Century: Authorship, Politics and History (Basingstoke: Palgrave Macmillan, 2005), pp.122123; Sara Mills, Discourses of Difference: An Analysis of Women's Travel Writing and Colonialism (London: Routledge, 1991); Indira Ghose, Women Travellers in Colonial India; The power of the female gaze (Delhi: Oxford University Press, 1998).

${ }^{12}$ Suleri, Rhetoric, pp.89-91.

${ }^{13}$ Charlotte Mathieson, Mobility in the Victorian Novel: Placing the Nation (Basingstoke: Palgrave Macmillan, 2015), pp.14-15. 
${ }^{14}$ Samuel Johnson, A dictionary of the English language: in which the words are deduced from their originals, explained in their different meanings and authorised by the names of the writers in whose works they are found, vol. $2,6^{\text {th }}$ edition (1785), p.1026

$<$ https://archive.org/details/dictionaryofeng102johnuoft $>$

${ }^{15}$ Elizabeth Bond, Letters of a Village Governess descriptive of Rural Scenery and Manners with Anecdotes of Highland children, vol. I (London: Longman Hurst, Rees, Orme and Brown, Paternoster Row; Manners and Miller, Edinburgh, 1814), p.19.

${ }^{16}$ Mary Wollstonecraft, $A$ Vindication of the Rights of Woman, Miriam Brody (ed. and intro.) (London: Penguin, 2004, first published 1792), p.78.

${ }^{17}$ Mrinalini Sinha, 'Mapping the Imperial Social Formation: A Modest Proposal for Feminist History', Signs 24 (2000), pp. 1077-1082.

${ }^{18}$ Maria Graham, 'Reminiscences' in Rosamund Brunel Gotch, Maria, Lady Callcott: the creator of 'Little Arthur' (London: John Murray, 1937), p.17.

${ }^{19}$ Maria Graham, 'Reminiscences', p. 7.

${ }^{20}$ For a critical biography of Maria Graham see Regina Akel, Maria Graham: a literary

biography (Amherst: Cambria Press, 2009). See also, Ghose, Women Travellers; Mary Louise Pratt, Imperial Eyes: travel writing and transculturation (London: Routledge, 1992); Carl Thompson, 'Earthquakes and Petticoats'.

${ }^{21}$ Graham, 'Reminiscences', p. 33 and pp. 40-43. 
22 'Journal of Reflections and Extracts made my Lady Callcott in 1806', Ms.Eng.e.2428, Bodleian Library, Oxford, pp. 6-11.

${ }^{23}$ Maria Graham to John Murray at 50 Abermarle St, May $31^{\text {st }} 1821$, Incoming letters of AW and Maria Callcott, Acc.12604/1185, John Murray Archive, National Library of Scotland; Elizabeth Hamilton to Mrs Liston, Clifton, March 22 $2^{\text {nd }} 1813$, MS 5640: Liston Constantinople, National Library of Scotland; Thomas Constable, Archibald Constable and His Literary Correspondents: A Memorial (Edinburgh: Edmonston and Douglas, 1873), vol. II, p. 284-5. See also, Jane Rendall, ‘The Condition of Women, Women's Writing and the Empire in NineteenthCentury Britain' in Catherine Hall and Sonya Rose (eds), At Home with the British Empire (Cambridge: Cambridge University Press, 2006), pp. 101-121 and Regina Akel, Maria Graham, ch. 1.

${ }^{24}$ S. N. Qanungo, 'Decline and Fall of the Maratha power (1799-1819)', in R.C. Majumdar (ed.), The Maratha Supremacy (Bombay: Bharatiya Vidya Bhavan, 1977), pp. 487-496.

${ }^{25}$ Pamela Nightingale, Trade and Empire in Western India, 1784-1806 (Cambridge: Cambridge University Press 1970); Meera Kosambi, 'Bombay and Poona: A Socio-Ecological Study of Two Indian Cities, 1650-1900' in MSA Rao, C Bhat, L N Kadeker (eds), A Reader in Urban Sociology (Hyderabad: Orient Longman, 1991), pp. 142-178.

${ }^{26}$ Alan Douglas Cameron, The Vellore Mutiny, unpublished PhD, University of Edinburgh (1984), pp. 50-51. 
${ }^{27}$ Karen Chancey, 'The Star in the East: the Controversy over Christian Missions to India, 18051813', Historian 16 (1988), pp. 507-522.

${ }^{28}$ See Nicholas Dirks, 'Colonial Histories and Native Informants: Biography of an Archive' in Carol A Breckenridge and Peter van der Veer (eds), Orientalism and the Postcolonial Predicament: Perspectives on South Asia (Philadelphia: University of Pennsylvania Press, 1993), pp. 279-313; Matthew Edney, Mapping an Empire: the Geographical Construction of British India, 1765-1843 (Chicago and London: University of Chicago Press, 1997), ch. 5.

${ }^{29}$ Graham, Journal, p. 99

${ }^{30}$ Graham, Journal, p. 98

${ }^{31}$ Graham, Journal, p. 96.

${ }^{32}$ Graham, Journal, p. 95.

${ }^{33}$ Alicia Schrikker, Dutch and British Colonial Intervention in Sri Lanka, 1780-1815: Expansion and Reform (Leiden and Boston: Brill, 2007), pp. 132-4.

${ }^{34}$ Schrikker, Dutch and British Colonial Intervention in Sri Lanka, p. 95.

${ }^{35}$ Schrikker, Dutch and British Colonial Intervention in Sri Lanka, p. 95.

${ }^{36}$ Schrikker, Dutch and British Colonial Intervention in Sri Lanka, p. 99.

${ }^{37}$ Schrikker, Dutch and British Colonial Intervention in Sri Lanka, p. 2.

${ }^{38}$ Suleri, Rhetoric of English India, p. 92.

${ }^{39}$ What Mary Louise Pratt calls 'the anti-conquest'. Imperial Eyes, p. 57.

${ }^{40}$ Graham, Journal, p. 77. 
${ }^{41}$ Graham, Journal, p. 59.
${ }^{42}$ Stewart Gordon, The New Cambridge History of India, vol. 2: The Marathas: 1600-1818
(Cambridge: Cambridge University Press, 1993), p. 118; S.N. Qanungo, 'Decline and Fall of the
Maratha power (1799-1819)' in R.C. Majumdar (ed), The Maratha Supremacy (Bombay:
Bharatiya Vidya Bhavan, 1977), p. 493.
${ }^{43}$ Qanungo, 'Decline and Fall,' p. $492-3$.
${ }^{44}$ Zirwat Chowdhury, 'An Imperial Mughal Tent and Mobile Sovereignty in Eighteenth-Century Jodhpur', Art History 38 (September, 2015), p. 668-681. Norbert Peabody, Hindu Kingship and Polity in Precolonial India (Cambridge: Cambridge University Press, 2003), pp. 50-54.

${ }^{45}$ M. Torri, 'Trapped inside the colonial order' in Georgio Borsa, Trade and Politics in the Indian Ocean (New Delhi: Manohar, 1990), pp. 54-57.

${ }^{46}$ Graham, Journal, p. 4.

${ }^{47}$ Graham, Journal p. 12.

${ }^{48}$ Graham, Journal p. 4 and p. 12.

${ }^{49}$ Mariam Dossal, Imperial Designs and Indian Realities: The Planning of Bombay City, 18471895 (Delhi: Oxford University Press, 1991); Amar Farooqui, Opium City: The Making of Early Victorian Bombay (New Delhi: Three Essays Collective, 2006); Claude Markovits, 'Bombay as a Business Centre in the Colonial Period: A Comparison with Calcutta' and Mariam Dossal, 'Signatures in space: Land Use in Colonial Bombay' in Bombay: Metaphor for Modern India, 
Sujata Patel and Alice Thorner (eds) (Bombay: Oxford University Press, 1995), pp. 26-46 and pp. 89-99.

${ }^{50}$ Graham, Journal, p. 4

${ }^{51}$ Graham, Journal, p. 21.

${ }^{52}$ Graham, Journal, p. 21.

${ }^{53}$ Graham, Journal, p. 101 and p. 6.

${ }^{54}$ Graham, Journal, p. 123

${ }^{55}$ Graham, Journal, p. 43.

${ }^{56}$ Graham, Journal, p. 26.

${ }^{57}$ Graham, Journal, p. 27.

${ }^{58}$ Graham, Journal, p. 27.

${ }^{59}$ See for example, William Robertson, An Historical Disquisition concerning The Knowledge which the Ancients had of India; and the progress of trade with that Country prior to the discovery of the passage to it by the Cape of Good Hope with and Appendix containing observations on the Civil Policy - the Laws and Judicial Proceedings - the Arts - the Sciences and Religious Institutions of the Indians. By William Robertson, D.D.F.R.S.Ed. Principal of the University and Historiographer to his Majesty for Scotland (London and Edinburgh, 1791). For British representations of Indian history, see: Ronald Inden, 'Orientalist Constructions of India', Modern Asian Studies 20 (1986), pp. 401-446; Rosanne Rocher, 'British Orientalism in the Eighteenth Century: the Dialectics of Knowledge and Government', in Breckinridge and van der 
Veer, Orientalism and the Postcolonial Predicament, pp. 215-249; Bernard Cohn, Colonialism and its Forms of Knowledge (Princeton: Princeton University Press, 1996); Theodore Koditschek, Liberalism, Imperialism and the Historical Imagination: Nineteenth-century Visions of a Greater Britain (Cambridge: Cambridge University Press, 2011), ch.2.

${ }^{60}$ Graham, Journal, p. 18.

${ }^{61}$ Graham, Journal, p. 19.

${ }^{62}$ Graham, Journal.

${ }^{63}$ Lady Mary Wortely Montagu, Turkish Embassy Letters, introduction by Anita Desai; text edited and annotated by Malcolm Jack (Athens, GA, 1993); Joanna de Groot, 'Oriental Feminotopias? Montagu's and Montesquieu's “Seraglios” Revisited', Gender \& History 18 (2006), pp. 66-86. Felicity Nussbaum, Torrid Zones: Maternity, Sexuality, and Empire in Eighteenth-Century English Narratives (Baltimore: The John Hopkins University Press, 1995); Janaki Nair, “Uncovering the Zenana: Visions of Indian Womanhood in Englishwomen's Writings, 1813-1940", Journal of Women's History 2 (1990), pp. 8-34.

${ }^{64}$ Graham, Journal, pp. $18-19$.

${ }^{65}$ Graham, Journal, p. 77.

${ }^{66}$ See for example, Sir William Jones, 'The Third Anniversary Discourse, delivered $2{ }^{\text {nd }}$ February 1786 by the President' in Lord Teignmouth (ed.), The Works of Sir William Jones with the Life of the Author in thirteen volumes, vol. III (London: Stockdale and Walker, 1807), p. 32. 
${ }^{67}$ Ann Laura Stoler, 'Rethinking Colonial Categories: European Communities and the Boundaries of Rule', Comparative Studies in Society and History 31 (1989), pp. 134-161.

${ }^{68}$ David Arnold, 'European orphans and vagrants in India in the nineteenth century', Journal of Imperial and Commonwealth History 7 (1979), pp. 104-27; Durba Ghosh, Sex and the Family in Colonial India: the making of Empire (Cambridge: Cambridge University Press, 2006).

${ }^{69}$ Graham, Journal, p. 134.

${ }^{70}$ Graham, Journal, p. 133.

${ }^{71}$ Graham, Journal, p. 134.

${ }^{72}$ Graham, Journal, p. 130

${ }^{73}$ BL Add MS 52451a, Mackintosh to Sharp, Bombay $14^{\text {th }}$ August, 1804.

${ }^{74}$ BL Add MS 78763, Mackintosh to Moore, $6^{\text {th }}$ August 1804, p. 155.

${ }^{75}$ Adam Smith, An Inquiry into the Nature and Causes of the Wealth of Nations, Book IV, Chapter V. Edwin Cannan, ed. 1904, Library of Economics and Liberty, $<$ http://www.econlif.org/library/Smith/smWN18.html $>$ [accessed: $9^{\text {th }}$ February 2016]; Jennifer Pitts, A Turn to Empire: the Rise of Imperial Liberalism in Britain and France (Princeton: Princeton University Press, 2005), pp. 33-34.

${ }^{76}$ Graham, Journal, p. 23.

${ }^{77}$ Graham, Journal, p. 63. 
${ }^{78}$ Mathieson, Mobility, p. 20; Sarah Jordan, The Anxieties of Idleness: Idleness in EighteenthCentury British Literature and Culture (Cranbury: Associated University Press, 2003), pp. 139143.

${ }^{79}$ John Locke, An Essay Concerning Human Understanding Locke (1690), South Bend, US:

Infomotions, Inc., 2000. ProQuest elibrary. [Accessed: 3 October 2016], p. 140.

${ }^{80}$ Quoted and discussed in Emmanuel Eze, Achieving our Humanity: the Idea of a Post-Racial Future (New York and London: Routledge, 2001), p. 23.

${ }^{81}$ Graham, Journal, p. 115

${ }^{82}$ See Miles Ogborn, Spaces of Modernity: London's geographies, 1680-1780 (New York: Guilford, 1998).

${ }^{83}$ For climate theory, see: David Allen Harvey, The French Enlightenment and its Others (New York: Palgrave Macmillan, 2102), pp. 136-141; Roxann Wheeler, Complexion of Race:

Categories of Difference in Eighteenth- Century Britain (Philadelphia: University of

Pennsylvania, 2000), pp. 23-27.

${ }^{84}$ Graham, Journal, p. 93.

${ }^{85}$ Graham, Journal, p. 27.

${ }^{86}$ C.A. Bayly, The New Cambridge History of India, vol II: Indian Society and the making of the British Empire (Cambridge: Cambridge University Press, 1988), pp. 76. P.J. Marshall, The Making and Unmaking of Empires: Britain, India and America, c.1750-1783 (Oxford: Oxford University Press, 2005), Nicholas Dirks, The Scandal of Empire: India and the creation of 
Imperial Britain (Cambridge: Harvard University Press, 2006); Robert Travers, Ideology and Empire in Eighteenth-century India: The British in Bengal (Cambridge: Cambridge University Press, 2007), pp. 218-9; Michael Dodson, Orientalism, Empire and National Culture: India 1770-1880 (Basingstoke: Palgrave Macmillan, 2007).

${ }^{87}$ See Javed Majeed, 'James Mill's “The History of British India” and Utilitarianism as a Rhetoric of Reform', Modern Asian Studies 24 (1990), p. 209.

${ }^{88}$ A.L. Gust, 'Empire, Exile, Identity: Locating Sir James Mackintosh's Histories of England', Unpublished PhD dissertation (UCL, 2010), ch. 3.

${ }^{89}$ Erica Wald, 'Defining Prostitution and Redefining Women's Roles: The Colonial State and Society in Early 19th Century India', History Compass 7/6 (2009), pp. 1470-1483. Durba Ghosh, Sex and the Family.

${ }^{90}$ Nussbaum, Torrid Zones, pp. 7-10; Silvia Sebastiani, The Scottish Enlightenment: Race, Gender and the Limits of Progress, tr. Jeremy Carden (New York: Palgrave Macmillan, 2013), p. 16.

${ }^{91}$ Charles Grant, Observations on the State of Society among the Asiatic subjects of Great Britain, particularly with respect to Morals and on the means of improving it - Written chiefly in the Year 1792. Ordered by The House of Commons to be printed 15 June 1813, p. 31. 
${ }^{92}$ Robert Orme, Historical fragments of the Mogul empire, of the Morattoes, and of the English concerns in Indostan from the year MDCLIX; origin of the company's trade at Broach and Surat, and a general idea of the government and people of Indostan (London: Wingrave, 1805), p. 472. ${ }^{93} \mathrm{~W}$. Ward, A View of the History, Literature and Religion of the Hindoos including a minute descript of their manners and customs in two volumes, vol. II (Serampore: Mission Press, 1815), p. lxxi $<$ https://archive.org/stream/aviewhistorylit01wardgoog\#page/n5/mode/2up $>$ [accessed, 29/02/2016]

${ }^{94}$ Graham, Journal, p. 115.

${ }^{95}$ Jordan, Anxieties of Idleness, 17-22.

${ }^{96}$ Wollstonecraft, Vindication, p. 78

${ }^{97}$ Wollstonecraft, Vindication, p. 79. For the relationship between femininity and race and the construction of the 'Other' woman, see Felicity Nussbaum, Torrid Zones: Maternity, Sexuality and Empire in Eighteenth-Century English Narratives (Baltimore: John Hopkins University Press, 1995), pp. 192-194.

${ }^{98}$ Nussbaum, Torrid Zones.

${ }^{99}$ Antoinette Burton and Tone Ballantyne's Moving Subjects: Gender, Mobility and Intimacy in an Age of Global Empire (Urbana: Univeristy of Illinois Press, 2009).

${ }^{100}$ For a theoretical discussion of mobility, see: Tanu Priya Uteng and Tim Cresswell, 'Gendered Mobilities: Towards and Holistic Understanding' in Uteng and Cresswell (eds) Gendered Mobilities (Aldershot: Ashgate, 2008), pp. 1-12. 


\footnotetext{
${ }^{101}$ Susan Wendell, The Rejected Body (New York: Routledge, 1996), ch. 2. See also: Helen Deutsch and Felicity Nussbaum, 'Introduction' in Deutsch and Nussbaum (eds), 'Defects': Engendering the Modern Body (Ann Arbor: The University of Michigan, 2000), pp. 3-4; Esme Cleall, "Deaf to the Word": Gender, Deafness and Protestantism in Nineteenth-Century Britain and Ireland', Gender and History 25 (2013), pp. 590-603. For the intersection between queer and disability theory see: Robert McRuer (ed.), Crip Theory: Cultural Signs of Disability and Theory (New York: New York University Press, 2006).

${ }^{102}$ On Western female individualism see Gayatri Spivak, 'Three Women’s Texts and a Critique of Imperialism', Critical Inquiry 12, 'Race', Writing and Difference (1985), pp. 243-261.

103 Jane Rendall, 'Bluestockings and Reviewers', p. 357.
} 